\title{
Screening for increased cardiometabolic risk in primary care:
}

\author{
a systematic review
}

\begin{abstract}
\section{Background}

Many programmes to detect and prevent cardiovascular disease (CVD) have been performed, but the optimal strategy is not yet clear.

\section{Aim}

To present a systematic review of cardiometabolic screening programmes performed among apparently healthy people (not yet known to have CVD, diabetes, or cardiometabolic risk factors) and mixed populations lapparently healthy people and people diagnosed with risk factor or disease) to define the optimal screening strategy.
\end{abstract}

\section{Design and setting}

Systematic review of studies performed in primary care in Western countries.

\section{Method}

MEDLINE, Embase, and CINAHL databases were searched for studies screening for increased cardiometabolic risk. Exclusion criteria were studies designed to assess prevalence of risk factors without follow-up or treatment; without involving a GP; when fewer than two risk factors were considered as the primary outcome; and studies constrained to ethnic minorities.

\section{Results}

The search strategy yielded 11445 hits; 26 met the inclusion criteria. Five studies (1995-2012) were conducted in apparently healthy populations: three used a stepwise method. Response rates varied from $24 \%$ to 79\%. Twenty-one studies (1967-2012) were performed in mixed populations; one used a stepwise method. Response rates varied from $50 \%$ to $75 \%$. Prevalence rates could not be compared because of heterogeneity of used thresholds and eligible populations. Observed time trends were a shift from mixed to apparently healthy populations, increasing use of risk scores, and increasing use of stepwise screening methods.

\section{Conclusion}

The optimal screening strategy in primary care is likely stepwise, in apparently healthy people, with the use of risk scores. Increasing public awareness and actively involving GPs might facilitate screening efficiency and uptake.

\section{Keywords}

cardiometabolic risk factors; primary health care; screening.

\section{INTRODUCTION}

Cardiovascular diseases (CVD) are the leading causes of death and disability worldwide. ${ }^{1}$ Early detection and treatment of cardiometabolic risk factors can prevent development of CVD. GPs could play a central role in primary prevention as they are easily accessible to patients. Performing screening in a familiar setting - inside the general practice - is likely to enhance participation. ${ }^{2}$ In addition, counselling and treatment could easily follow screening, as these are already part of usual care.

Screening programmes can be performed among apparently healthy individuals (not yet known to have CVD, diabetes, or cardiometabolic risk factors) and in mixed populations lincluding apparently healthy people and people already diagnosed with a risk factor or established disease). Screening entire populations could lead to considerable unnecessary testing, with a fairly low yield, as most people screened will be healthy. Other ways of screening have been advocated, for example, targeted or stepwise screening methods. ${ }^{3}$ In targeted screening, a presumed high-risk group is considered, for example, people with central (abdominal) obesity. Stepwise methods can be used to identify high-risk groups, thereby limiting the number of people qualifying for further examinations.

Even though many screening programmes have been conducted in primary care over

C den Engelsen, MD, PhD, GP and researcher: P S Koekkoek, MD, GP and professor; G E Rutten, MD, PhD, Julius Center for Health Sciences and Primary Care, University Medical Center Utrecht, the Netherlands. M B Godefrooij, MD, GP and researcher; M G Spigt, PhD, assistant professor, CAPHRI-School for Public Health and Primary Care, Department of General Practice, Faculty of Health, Medicine and Life Sciences, Maastricht University, Maastricht, the Netherlands

\section{Address for correspondence}

Paula S Koekkoek, Julius Center for Health recent decades, no attempt had been made to compare the various approaches and define lessons. In the authors' opinion, the optimal screening strategy should identify all people with an increased cardiometabolic risk, with a minimum effort to detect these people. Therefore, this study was a systematic review of cardiometabolic screening programmes in a primary care setting. The aim was to define the optimal screening strategy, by focusing on the population in which the screening was performed, the approach taken with patients, the different screening steps, the uptake, and the yield of screening.

\section{METHOD}

\section{Criteria for considering studies for this review}

In this study, the focus was on screening studies that were aimed at detecting an increased cardiometabolic risk, performed in primary care. Studies were excluded when they assessed only the prevalence of risk factors without further follow-up or treatment; those without involving a GP in the screening process; when fewer than two cardiometabolic risk factors (hypertension, dyslipidaemia, impaired glucose tolerance, diabetes, overweight/obesityl were considered as the primary outcome; and those with study populations constrained to an ethnic minority.

It was assumed that people with established disease or risk factors already

Sciences and Primary Care, University Medical Center Utrecht, STR.6.131, P.0. Box 85500; 3508 GA Utrecht, the Netherlands.

E-mail: p.s.koekkoek-3dumcutrecht.nl

Submitted: 1 February 2014; Editor's response: 25 March 2014; final acceptance: 20 May 2014 (CBritish Journal of General Practice

This is the full-length article (published online 29 Sep 2014) of an abridged version published in print. Cite this article as: Br J Gen Pract 2014; DOI: 10.3399/bjgp14X681781 


\section{How this fits in}

Screening programmes can identify cardiometabolic risk factors that, when treated, can prevent development of cardiovascular disease. Several strategies, settings, and populations can be eligible. This study defines that the optimal screening strategy in primary care could be a stepwise approach, using, for example, risk scores to select people qualifying for further screening examinations. Increasing public awareness and actively involving GPs may facilitate screening efficiency and uptake.

receive extensive care through existing pathways, although this probably only applies to countries with a well-established primary care system. Therefore, only studies performed in Western countries were included: European countries, Australia, New Zealand, Canada, and the US.

\section{Search methods}

The MEDLINE, Embase, and CINAHL

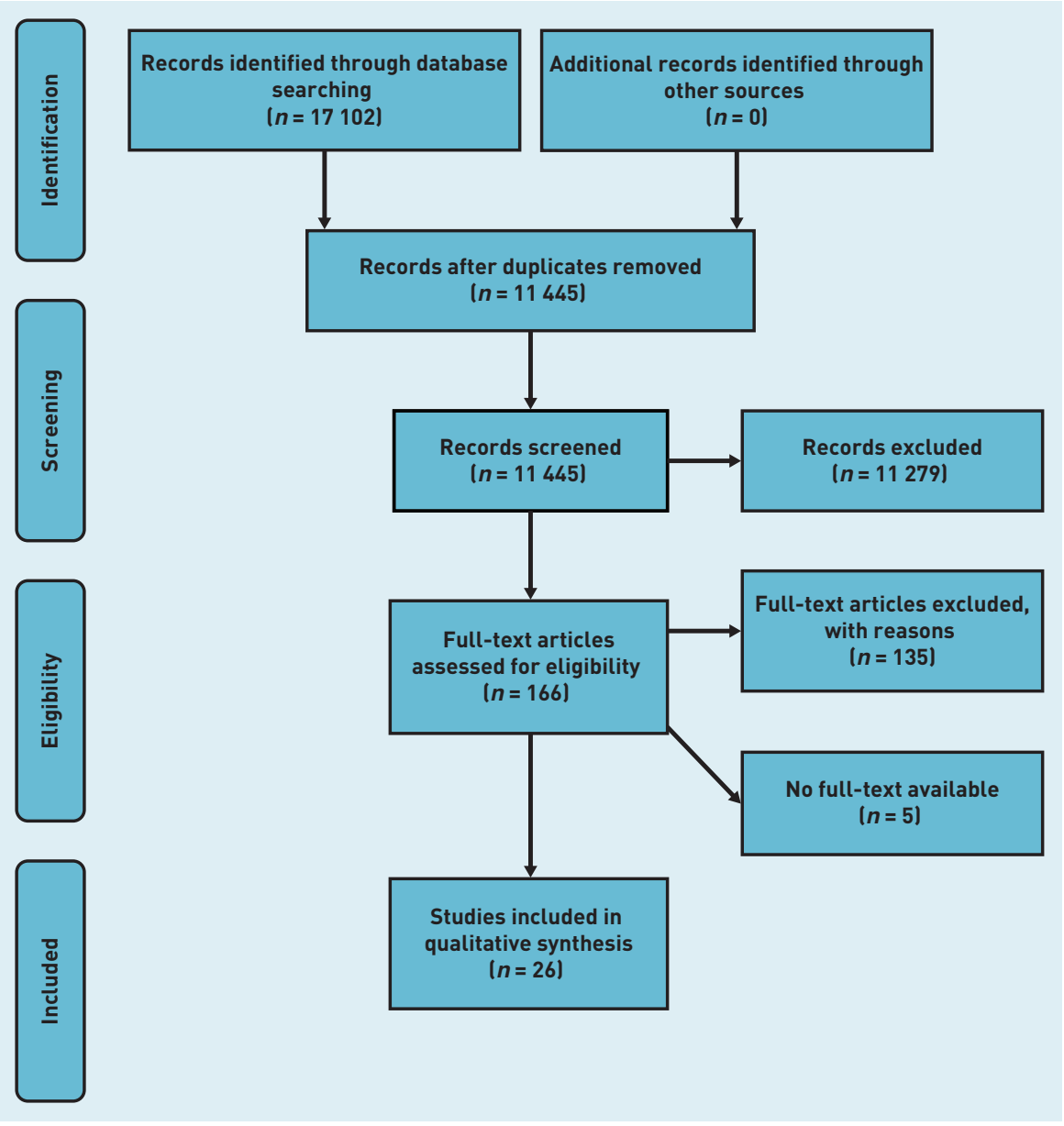

for primary care, screening, and cardiometabolic risk factors, on 27 January 2013. For the detailed search strategy see Appendix 1 lavailable from the authors on request). Language was restricted to English.

\section{Data collection and analysis}

Two reviewers independently checked all titles and abstracts. Potentially relevant articles were retrieved full-text, and subsequently assessed for inclusion by two reviewers independently. When a fulltext article was not available, the author and/or editor was contacted. In cases of disagreement between two reviewers, these were discussed and resolved by the third reviewer.

For included studies, relevant data were extracted using a standardised template. Data were extracted on the screened population, screening method, patient approach, response rates, and yield of screening in terms of detected cardiometabolic risk factors. When more than one article reported on the same study population, the article with the most information on the method was included.

\section{RESULTS}

\section{Included studies}

Figure 1 represents the study flow diagram. The search strategy yielded 11445 hits, of which 26 met the study inclusion criteria. Data on population characteristics, screening method, patient approach, and response rates are listed in Tables 1 (apparently healthy populations) and 2 (mixed populations).

The first four studies concerning screening for cardiovascular risk were published between 1967 and 1972.4-7 These were all so-called multiple screening studies: besides cardiovascular risk factors the screening programmes also screened for other diseases like glaucoma, anaemia, or cervical cancer. The first study that focused solely on screening for an increased cardiovascular risk was published in 1978. ${ }^{8}$

\section{Screening population}

Apparently healthy populations. Five studies focused on apparently healthy patients only (Table 1), ${ }^{9-13}$ including the four most recently published. The number of people eligible for screening ranged from 361 to 24166 . Four studies defined a specific age-category, the lower threshold varying between 20 and 40 years and the upper threshold varying between 69 and 75 years. Only the study by Lambert et al set a minimum age, excluding males $<40$ years. $^{10}$ 


\section{Table 1. Overview of included screening initiatives, performed in an apparently healthy population}

\begin{tabular}{|c|c|c|c|c|c|c|c|}
\hline & Study name & Country & $\begin{array}{l}\text { Age, } \\
\text { years }\end{array}$ & $\begin{array}{l}\text { Screening } \\
\text { method }\end{array}$ & Approach & $\begin{array}{l}\text { Number } \\
\text { eligible }\end{array}$ & $\begin{array}{l}\text { Response } \\
\text { rate }\end{array}$ \\
\hline $\begin{array}{l}\text { McMenamin, } \\
1995^{12}\end{array}$ & NA & New Zealand & $30-69$ & $\begin{array}{l}\text { Eligible males were invited by the } \\
\text { doctor when attending the surgery } \\
\text { to return for a preventive health check }\end{array}$ & Opportunistic & 361 males $^{a}$ & $79 \%$ \\
\hline $\begin{array}{l}\text { Marshall et al, } \\
2008^{11 ~ b}\end{array}$ & $\begin{array}{c}\text { l, The Sandwell } \\
\text { Project }\end{array}$ & England & $35-74$ & $\begin{array}{l}\text { For all patients without known } \\
\text { CVD and not currently receiving } \\
\text { antihypertensive medication, a } \\
\text { Framingham risk score calculation } \\
\text { was made with data from medical } \\
\text { records. Default risk factor values } \\
\text { were used for all missing risk factor } \\
\text { data. Those with a risk }>20 \% \text { were } \\
\text { mailed an appointment to attend a } \\
\text { CVD assessment in their practice }\end{array}$ & $\begin{array}{l}\text { Actively } \\
\text { invited, } \\
\text { stepwise }\end{array}$ & $\begin{array}{c}11901 ; \\
598 \text { invited } \\
\text { for second } \\
\text { step }\end{array}$ & $\begin{array}{l}62 \% \text { of those } \\
\text { invited for risk } \\
\text { assessment }\end{array}$ \\
\hline $\begin{array}{l}\text { Van den Donk } \\
\text { et al, } 2009^{13}\end{array}$ & IJSCO & Netherlands & $20-70$ & $\begin{array}{l}\text { Patients not known to have a } \\
\text { diagnosis of CVD, DM, hypertension, } \\
\text { or dyslipidaemia received a tape } \\
\text { measure mailed to their home and } \\
\text { were asked to measure their own WC. } \\
\text { Those with an increased WC were } \\
\text { invited for further risk assessment }\end{array}$ & $\begin{array}{l}\text { Actively } \\
\text { invited, } \\
\text { stepwise }\end{array}$ & $\begin{array}{c}11862 ; \\
2004 \text { invited } \\
\text { for second } \\
\text { step }\end{array}$ & $\begin{array}{l}50 \% \text { measured } \\
\text { their own WC; } \\
86 \% \text { of those with } \\
\text { an increased WC } \\
\text { underwent all } \\
\text { screening } \\
\text { examinations }\end{array}$ \\
\hline $\begin{array}{l}\text { Godefrooij } \\
\text { et al, 2012 }\end{array}$ & NA & Netherlands & $40-75$ & $\begin{array}{l}\text { Patients without a diagnosis of CVD, } \\
\text { cerebrovascular disease, DM, } \\
\text { hypertension, or dyslipidaemia, were } \\
\text { asked to return a questionnaire. } \\
\text { Based on this questionnaire a risk } \\
\text { score was calculated and patients at } \\
\text { risk were invited for further } \\
\text { risk assessment }\end{array}$ & $\begin{array}{l}\text { Actively } \\
\text { invited, } \\
\text { stepwise }\end{array}$ & 1704 & $\begin{array}{l}75 \% \text { returned } \\
\text { questionnaire; } \\
72 \% \text { of those } \\
\text { invited for further } \\
\text { risk assessment } \\
\text { attended screening }\end{array}$ \\
\hline $\begin{array}{l}\text { Lambert } \\
\text { et al, } 2012^{10}\end{array}$ & $\begin{array}{l}\text { The Deadly } \\
\text { Trio Programme }\end{array}$ & England & $\geq 40$ & $\begin{array}{l}\text { Males who were not registered in a } \\
\text { disease register for } \mathrm{CHD} \text {, hypertension, } \\
\mathrm{DM}, \mathrm{CKD} \text {, heart failure, or atrial } \\
\text { fibrillation were invited for cardiovascular } \\
\text { assessment either by their own GP or an } \\
\text { alternative provider }\end{array}$ & $\begin{array}{l}\text { Actively } \\
\text { invited }\end{array}$ & 24166 males & $24 \%$ \\
\hline
\end{tabular}

$C H D=$ chronic heart disease. $C K D=$ chronic kidney disease. $C V D=$ cardiovascular disease. $D M=$ diabetes mellitus. NA = not applicable. WC $=$ waist circumference. ${ }^{\text {I }}$. case of an opportunistic approach: the number of eligible people refers to the number of people who attended screening. ${ }^{b}$ Results only represent the intervention group.

Mixed populations. Twenty-one screening programmes were performed in mixed populations (Table 2).4-7.14-27 The British Family Heart Study reported which part of their study population was not previously diagnosed with coronary heart disease, high blood pressure, high cholesterol, or diabetes. None of the other studies provided any information about the composition of their study population. Most studies included males and females. The number of people eligible for screening ranged from 120 to 40000 . Sixteen studies defined a specific age-category, with lower thresholds from 15 to 45 years and upper thresholds from 50 to 65 years. The remaining studies excluded school children, ${ }^{4,7}$ or specifically considered older patients. $5,26,28$

\section{Screening method}

Apparently healthy populations. Three of the fivestudies performed inanapparentlyhealthy population used a stepwise approach. $9.11,13$ Calculation of a risk score based on a questionnaire completed by patients, ${ }^{9}$ data available in electronic medical records, ${ }^{11}$ or self-measuring waist circumference, ${ }^{13}$ were used as first screening steps; subsequently people with scores above a threshold were invited for additional examinations.

Mixed populations. Hellénius et al were the only group to use a stepwise approach in a mixed population. People were asked to fill in a questionnaire about the presence of cardiometabolic and lifestyle risk factors. Those with at least one risk factor were 
Table 2. Overview of included screening initiatives, performed in a mixed population: screening methods, patient approach, and response rate

\begin{tabular}{|c|c|c|c|c|c|c|c|}
\hline & $\begin{array}{l}\text { Study } \\
\text { name }\end{array}$ & Country & $\begin{array}{l}\text { Age, } \\
\text { years }\end{array}$ & $\begin{array}{l}\text { Screening } \\
\text { method }\end{array}$ & Approach & $\begin{array}{l}\text { No. } \\
\text { eligible }\end{array}$ & $\begin{array}{l}\text { Response } \\
\text { rate }\end{array}$ \\
\hline $\begin{array}{l}\text { Cope } \\
\text { et al, } 1967^{4}\end{array}$ & NA & England & $>15$ & $\begin{array}{l}\text { All people responding to posters, } \\
\text { talks, and other advertising literature } \\
\text { that was distributed throughout } \\
\text { the practice were screened }\end{array}$ & Opportunistic & $1711^{\mathrm{a}}$ & $39 \%$ \\
\hline $\begin{array}{l}\text { Scott } \\
\text { et al, } 1968^{7}\end{array}$ & NA & England & $\geq 15$ & $\begin{array}{l}\text { All eligible females in one practice } \\
\text { were invited for an examination }\end{array}$ & Actively invited & 1800 females & $43 \%$ \\
\hline Pike, $1969^{5}$ & NA & England & $>68$ & $\begin{array}{l}\text { All eligible patients were sent a letter } \\
\text { to invite them for a series of tests }\end{array}$ & Actively invited & 671 & $43 \%$ \\
\hline Pike, $1972^{6}$ & NA & England & $45-55$ & $\begin{array}{l}\text { Eligible males were sent a letter } \\
\text { inviting them to attend a morning } \\
\text { for examinations and interviews }\end{array}$ & Actively invited & 309 males & $45 \%$ \\
\hline Brown, $1978^{8}$ & NA & England & $37-43$ & $\begin{array}{l}\text { All eligible males were sent a } \\
\text { letter inviting them to attend for a } \\
\text { screening test in the morning }\end{array}$ & Actively invited & 120 males & $64 \%$ \\
\hline $\begin{array}{l}\text { Anggard } \\
\text { et al, } 1986^{16}\end{array}$ & NA & England & $20-59$ & $\begin{array}{l}\text { Patients could attend screening at } \\
\text { their own request or were invited } \\
\text { during a regular consultation }\end{array}$ & Opportunistic & $40000^{a}$ & Unknown \\
\hline $\begin{array}{l}\text { Jones } \\
\text { et al, } 1988^{23}\end{array}$ & NA & $\begin{array}{l}\text { England, } \\
\text { Wales }\end{array}$ & $25-55$ & $\begin{array}{l}\text { All patients were invited for } \\
\text { screening and those with any of } \\
\text { the risk factors were referred } \\
\text { for treatment }\end{array}$ & Actively invited & 3800 & $62 \%$ \\
\hline $\begin{array}{l}\text { Mann } \\
\text { et al, } 1988^{25}\end{array}$ & NA & England & $25-59$ & $\begin{array}{l}\text { Two approaches in different } \\
\text { centres: } 1 \text {. All eligible patients } \\
\text { invited; } 2 \text {. Patients visiting clinic } \\
\text { offered a health check consultation }\end{array}$ & Invited/opportunisti & $12092^{a}$ & $73 \%$ \\
\hline $\begin{array}{l}\text { Bennett } \\
\text { et al, } 198917\end{array}$ & $\begin{array}{l}\text { South } \\
\text { Birmingham } \\
\text { Coronary } \\
\text { Prevention Project }\end{array}$ & England & $35-65$ & $\begin{array}{l}\text { People attending the GPs } \\
\text { surgery were invited to } \\
\text { participate, alternatively } \\
\text { invitations were sent by post }\end{array}$ & Invited/opportunistic & $2261^{a}$ & Unknown \\
\hline $\begin{array}{l}\text { OXCHECK } \\
\text { Study Group, } \\
1991^{14}\end{array}$ & OXCHECK & England & $35-64$ & $\begin{array}{l}\text { Eligible people were invited } \\
\text { for a health check and } \\
\text { randomised for participation } \\
\text { in the first, second, third, or } \\
\text { fourth study year }\end{array}$ & Actively invited & $\begin{array}{c}11090 \text { responded } \\
\text { to initial } \\
\text { questionnaire; } \\
2674 \text { were } \\
\text { randomised for } \\
\text { participation in } \\
\text { the first year }\end{array}$ & $\begin{array}{l}73 \% \text { responded } \\
\text { to questionnaire, } \\
82 \% \text { of those } \\
\text { invited for first- } \\
\text { year screening } \\
\text { accepted }\end{array}$ \\
\hline $\begin{array}{l}\text { Hellénius } \\
\text { et al, } 1993^{22}\end{array}$ & NA & Sweden & $15-60$ & $\begin{array}{l}\text { All eligible people visiting the } \\
\text { health centre were offered } \\
\text { the opportunity to fill in a } \\
\text { short questionnaire. Those } \\
\text { with } \geq 1 \text { risk factor (known } \\
\text { hypertension, hyperlipidaemia, DM, } \\
\text { smoking, overweight, physical } \\
\text { inactivity, family history of early CVD } \\
\text { or symptoms of angina pectoris } \\
\text { or intermittent claudication) } \\
\text { were offered a free check-up }\end{array}$ & $\begin{array}{l}\text { Opportunistic, } \\
\text { stepwise }\end{array}$ & $\begin{array}{l}1904 \text { filled in risk } \\
\text { questionnaire, } \\
94 \% \text { were eligible } \\
\text { for the second step }\end{array}$ & $6 \%$ \\
\hline $\begin{array}{l}\text { Family Heart } \\
\text { Study Group, } \\
1994^{15}\end{array}$ & $\begin{array}{l}\text { British } \\
\text { Family } \\
\text { Heart Study }\end{array}$ & $\begin{array}{l}\text { England, } \\
\text { Wales, } \\
\text { Scotland }\end{array}$ & $40-59$ & $\begin{array}{l}\text { Eligible patients were } \\
\text { identified by household } \\
\text { through the male partner; } \\
\text { families were screened }\end{array}$ & Actively invited & $\begin{array}{l}4158 \text { males and } \\
\text { their families } \\
\text { were invited }\end{array}$ & $\begin{array}{l}57 \% \text { of the } \\
\text { families were } \\
\text { represented by } \\
\text { one or more } \\
\text { member }\end{array}$ \\
\hline
\end{tabular}


Table 2 continued. Overview of included screening initiatives, performed in a mixed population: screening methods, patient approach, and response rate

\begin{tabular}{|c|c|c|c|c|c|c|c|}
\hline & $\begin{array}{l}\text { Study } \\
\text { name }\end{array}$ & Country & $\begin{array}{l}\text { Age, } \\
\text { years }\end{array}$ & $\begin{array}{l}\text { Screening } \\
\text { method }\end{array}$ & Approach & $\begin{array}{l}\text { No. } \\
\text { eligible }\end{array}$ & $\begin{array}{l}\text { Response } \\
\text { rate }\end{array}$ \\
\hline $\begin{array}{l}\text { Persson } \\
\text { et al, 1994 }\end{array}$ & & Sweden & $33-42$ & $\begin{array}{l}\text { All eligible males received a postal } \\
\text { invitation to a health examination }\end{array}$ & Actively invited & 757 & $86 \%$ \\
\hline $\begin{array}{l}\text { Gran } \\
\text { et al,199521 }\end{array}$ & NA & Sweden & $30-59$ & $\begin{array}{l}\text { All people living in one primary } \\
\text { healthcare centre's catchment } \\
\text { area were invited to participate } \\
\text { in a population-based screening } \\
\text { programme }\end{array}$ & Actively invited & 3884 & $68 \%$ \\
\hline $\begin{array}{l}\text { Lauritzen } \\
\text { et al, } 1995^{24}\end{array}$ & $\begin{array}{l}\text { Ebeltoft } \\
\text { project }\end{array}$ & Denmark & $30-50$ & $\begin{array}{l}\text { Random sample of all inhabitants } \\
\text { of Ebeltoft who were registered } \\
\text { with one of the study practices } \\
\text { received an invitation. Those willing } \\
\text { to participate received a } \\
\text { questionnaire and were randomised } \\
\text { in three groups: one control group } \\
\text { and two intervention groups (health } \\
\text { check and written feedback with } \\
\text { or without consultation of GP) }\end{array}$ & Actively invited & $\begin{array}{l}2000 \text { were invited; } \\
1370 \text { were willing } \\
\text { to participate } \\
\text { (control: 465; } \\
\text { intervention: } \\
449 \text { and } 456 \text { ) }\end{array}$ & $69 \%$ \\
\hline $\begin{array}{l}\text { van den Berg } \\
\text { et al, } 199926\end{array}$ & NA & Netherlands & $\geq 60$ & $\begin{array}{l}\text { All persons registered with one } \\
\text { general practice received } \\
\text { a letter from their GP offering } \\
\text { a cardiovascular health check }\end{array}$ & Actively invited & 1002 & $80 \%$ \\
\hline $\begin{array}{l}\text { Weinehall } \\
\text { et al, } 199927\end{array}$ & $\begin{array}{l}\text { Västerbotten } \\
\text { Intervention } \\
\text { Programme }\end{array}$ & Sweden & $30-60$ & $\begin{array}{l}\text { All people aged } 30,40,50 \text {, and } \\
60 \text { years of age were invited } \\
\text { annually to a health provider } \\
\text { survey focusing on the traditional } \\
\text { risk factors for CVD }\end{array}$ & Actively invited & $2046^{b}$ & $93 \%$ \\
\hline $\begin{array}{l}\text { Devroey } \\
\text { et al, } 2004^{20}\end{array}$ & NA & Belgium & $45-64$ & $\begin{array}{l}\text { All inhabitants of three Belgian } \\
\text { towns were invited. An information } \\
\text { campaign in the local press had } \\
\text { been set up to augment the recruitment }\end{array}$ & Actively invited & 12756 & $7 \%$ \\
\hline $\begin{array}{l}\text { Tiessen } \\
\text { et al, } 2012^{28}\end{array}$ & NA & Netherlands & $>50$ & $\begin{array}{l}\text { Males }>50 \text { and females }>55 \text { years, } \\
\text { without registered DM and not } \\
\text { under second-line follow-up by a } \\
\text { cardiologist or internist, were } \\
\text { invited for assessment } \\
\text { of CVD risk by their GP }\end{array}$ & Actively invited & 521 & $\begin{array}{l}82 \% \text { responded; } \\
68 \% \text { participated }\end{array}$ \\
\hline
\end{tabular}

$C V D=$ cardiovascular disease. $D M=$ diabetes mellitus. $N A=$ not applicable. ${ }^{a} / n$ case of an opportunistic approach: the number of eligible people refers to the number of people who attended screening. ${ }^{b}$ This is the total number of people invited over 8 consecutive screening years.

invited for further examinations. ${ }^{22}$

\section{Patient approach}

Apparently healthy populations. Four studies in apparently healthy populations actively invited people to participate in the screening, by a written invitation from their GP, $, 11,13$ or by either their own GP or an alternative provider. ${ }^{10}$ One study used an opportunistic approach: eligible males were asked during a regular GP visit to participate in screening..$^{12}$

Mixed populations. Most studies performed in mixed populations actively invited people.
Five studies used a different approach. Two studies asked people to participate in screening during a regular GP visit; ${ }^{22}$ in one of them people could also attend on their own request. ${ }^{16}$ Cope et al informed people about the screening through public advertising inside and outside the general practice. ${ }^{4}$ Two studies combined the active and opportunistic approaches. ${ }^{17,25}$

\section{Response rate}

Apparently healthy populations. Four studies performed among apparently healthy people had response rates between 
Table 3. Overview of included screening initiatives, performed in an apparently healthy population: yield of screening

\begin{tabular}{|c|c|c|c|c|c|}
\hline & \multicolumn{4}{|c|}{ Risk factors } & \multirow[b]{2}{*}{ Risk score } \\
\hline & Obesity & Hypertension & Diabetes & Dyslipidaemia & \\
\hline $\begin{array}{l}\text { McMenamin, } \\
1995^{12}\end{array}$ & & DBP > $90: 9 \%$ & & $\mathrm{TC}>7.5 \mathrm{mmol} / \mathrm{l}: 8 \%$ & $\begin{array}{l}\text { High CHD-risk: } 10 \% \\
\text { Moderate risk: } 14 \%\end{array}$ \\
\hline $\begin{array}{l}\text { Marshall et al, } \\
2008^{11} \text { a }\end{array}$ & & $\begin{array}{c}28 \% \text { eligible for } \\
\text { antihypertensive treatment }\end{array}$ & & $49 \%$ eligible for statin & $\begin{array}{l}\text { Framingham risk score }>20 \% \\
\text { in first screening step: } 9 \%\end{array}$ \\
\hline $\begin{array}{l}\text { van den Donk } \\
\text { et al, 200913 }\end{array}$ & $\begin{array}{c}\text { WC >88/102 cm } \\
\text { (females/males): } \\
34 \%\end{array}$ & & & & $\begin{array}{c}\text { Metabolic syndrome: } \\
28 \% \text { of those people with } \\
\text { a self-measured WC }>88 / 102 \mathrm{~cm}\end{array}$ \\
\hline $\begin{array}{l}\text { Godefrooij } \\
\text { et al, } 2011^{9}\end{array}$ & $\mathrm{BMI} \geq 25: 51 \%$ & $\mathrm{SBP} \geq 180: 2 \%$ & $\mathrm{FBG} \geq 7: 2 \%$ & $\begin{array}{l}\mathrm{TC} \geq 8.0 \mathrm{mmol} / \mathrm{l}: 0.4 \% \\
\mathrm{LDL} \geq 5.0 \mathrm{mmol} / \mathrm{l}: 1 \%\end{array}$ & SCORE risk function $\geq 10 \%: 6 \%$ \\
\hline $\begin{array}{l}\text { Lambert } \\
\text { et al, 2012 }\end{array}$ & & $\begin{array}{l}6 \% \text { was added to } \\
\text { hypertension register; } \\
\text { an additional } 20 \% \\
\text { had BP }>140\end{array}$ & $\begin{array}{l}3 \% \text { was added to } \\
\text { diabetes register }\end{array}$ & $\mathrm{TC}>5 \mathrm{mmol} / \mathrm{l}: 45 \%$ & $\begin{array}{c}\text { Framingham risk score } \\
\geq 20 \%: 20 \%\end{array}$ \\
\hline
\end{tabular}

$B M I=$ body mass index in $\mathrm{kg} / \mathrm{m}^{2} . B P=$ blood pressure in $\mathrm{mmHg} . \mathrm{CHD}=$ coronary heart disease. $D B P=$ diastolic blood pressure in $\mathrm{mmHg}$. FBG = fasting blood glucose in mmol/l. HbAlc = haemoglobin A1c in mmo/ll. $L D L=L o w$-density lipoprotein cholesterol. $R B G=$ random blood glucose in mmol/l. SBP $=$ systolic blood pressure in mmHg. $T C=$ total cholesterol. $W C=$ waist circumference. ${ }^{a}$ Results only represent those of the intervention group.

$50 \%$ and $79 \%$; if necessary, one or more reminders were sent. One study had a lower response rate of $24 \%$; sending reminders was not reported. ${ }^{10}$ The age group eligible for screening did not seem to influence the response rate. The study with the highest rate was the only one with an opportunistic approach and lasted for 3 years. ${ }^{12}$

Mixed populations. Response rates in mixed populations ranged from $6 \%$ to $93 \%$. The age group eligible for screening did not seem to influence the response rate. The lowest response rate $(6 \%)$ was observed by Hellénius et al using a stepwise method and an opportunistic approach. ${ }^{22}$ Devroey et al reported a rate of $7 \%$; in this study the local authorities invited all inhabitants of three Belgian towns to visit their GP for a health check. ${ }^{20}$ The highest response rate was found in the Swedish Västerbotten Intervention Programme, in which all people of a specific age were annually invited. ${ }^{27}$

\section{Yield in terms of cardiometabolic risk}

Apparently healthy populations. An overview of the yield of the studies in apparently healthy populations is given in Table 3 . Four studies calculated a CVD risk score for participants. The results varied from a 10 -year cardiovascular mortality risk $\geq 10 \%$ in $6 \%$ of the study population, ${ }^{9}$ to a 10 -year cardiovascular mortality and morbidity risk $\geq 20 \%$ in $20 \%$ of the study population. ${ }^{10}$

Mixed populations. The yield of the studies performed in mixed populations is presented in Table 4. All but one of the studies measuring obesity (BMI $\left.\geq 30 \mathrm{~kg} / \mathrm{m}^{2}\right)$ report prevalence rates between $10 \%$ and $21 \%$. This percentage does not clearly increase in the more recent studies. The yield of diabetes ranged from $1 \%$ to $3 \%$. Prevalence of hypercholesterolaemia (total cholesterol $\geq 6.5 \mathrm{mmol} / \mathrm{l}$ ) ranged between $24 \%$ and $48 \%$ for females, and $26 \%$ and $46 \%$ for males. ${ }^{14,17,21,22,25-27}$ Seven studies calculated a cardiovascular risk score for participants: : $5,16,19-21,24,28$ five studies reported results. ${ }^{15,19,20,24,28}$

Apparently healthy people versus a mixed population. The British Family Heart Study Group is the only study performed in a mixed population that separately reports results for their apparently healthy subpopulation. ${ }^{15}$ Of the 2246 males, 1716 were apparently healthy, and of the 1604 females, 1321 were apparently healthy. The prevalence rates were comparable or slightly lower in the apparently healthy population. A diastolic blood pressure $\geq 90 \mathrm{mmHg}$ was present in $38 \%$ and $23 \%$ of all males and females, and in $33 \%$ and $18 \%$ of the apparently healthy males and females, respectively. For a total cholesterol level $\geq 6.5 \mathrm{mmol} / \mathrm{l}$, the prevalence rates were $22 \%$ and $18 \%$ for all males and females, and $19 \%$ and $16 \%$ for the apparently healthy males and females.

\section{DISCUSSION}

\section{Summary}

To the best of the authors' knowledge, 
Table 4. Overview of included screening initiatives, performed in a mixed population: yield of screening

\begin{tabular}{|c|c|c|c|c|c|}
\hline & \multicolumn{4}{|c|}{ Risk factors } & \multirow[b]{2}{*}{ Risk score } \\
\hline & Obesity & Hypertension & Diabetes & Dyslipidaemia & \\
\hline $\begin{array}{l}\text { Cope et al, } \\
1967^{4}\end{array}$ & & $\begin{array}{l}\mathrm{DBP}>100 \text { or } \\
\mathrm{SBP}>150: 3 \%\end{array}$ & $0.3 \%$ & & \\
\hline $\begin{array}{l}\text { Scott et al, } \\
1968^{7}\end{array}$ & $\begin{array}{c}>10 \% \text { above } \\
\text { ideal weight: } 30 \%\end{array}$ & DBP >90: $16 \%$ & $\begin{array}{c}\text { IFG: } 4 \% ; \\
2 \text { people had DM }\end{array}$ & TC > $260 \mathrm{mg} / 100 \mathrm{ml}: 19 \%$ & \\
\hline Pike, $1969^{5}$ & $\begin{array}{l}6 \% \text { females and } \\
7 \% \text { males required } \\
\text { advice to reduce } \\
\text { their weight }\end{array}$ & $\begin{array}{l}8 \text { females and } 9 \text { males } \\
\text { had symptoms that } \\
\text { could be associated with } \\
\text { hypertension; more } \\
\text { had } \mathrm{SBP}>200 \text {, or DBP }>120\end{array}$ & $\begin{array}{l}\text { Glycosuria: } 2 \% \text { females, } \\
3 \% \text { males (apart from } \\
\text { the known diabetics); } \\
\text { one male had DM }\end{array}$ & & \\
\hline Pike, $1972^{6}$ & $\begin{array}{c}\text { Obesity (estimated } \\
\text { by skin-fold calliper } \\
\text { and height/weight } \\
\text { tables): } 31 \%\end{array}$ & DBP >105: $5 \%$ & Glycosuria: $0.7 \%$ & TC > 250 mg/100 ml: 12\% & \\
\hline Brown, $1978^{8}$ & $\begin{array}{c}7 \% \text { were } \\
\text { considered overweight }\end{array}$ & & $0 \%$ & $\begin{array}{c}\text { TC }>6.5 \mathrm{mmol} / \mathrm{l} \text { or } \\
\mathrm{TG}>1.7 \mathrm{mmo} / \mathrm{l}: 20 \%\end{array}$ & \\
\hline $\begin{array}{l}\text { Anggard } \\
\text { et al, 1986 }\end{array}$ & & $\begin{array}{l}\text { SBP }>160: 6 \% \\
\text { DBP > } 95: 10 \%\end{array}$ & & $\mathrm{TC}>7.0 \mathrm{mmol} / \mathrm{l}: 15 \%$ & $\begin{array}{l}\text { A risk score was calculated, } \\
\text { results not reported }\end{array}$ \\
\hline $\begin{array}{l}\text { Jones et al, } \\
1988^{23}\end{array}$ & & $\begin{array}{c}\text { BP }>150 / 90 \text { (<40 years) } \\
\text { or }>155 / 95 \text { ( } \geq 40 \text { years): } 3 \%\end{array}$ & $\begin{array}{l}\text { Glycosuria: } 2 \% \\
\text { Proteinuria: } 2 \%\end{array}$ & $\begin{array}{c}\mathrm{TC}>6.0 / 6.5 \mathrm{mmol} / \mathrm{l} \\
\text { (female/male, }<30 \text { years) } \\
\text { or }>6.5 / 7.1 \mathrm{mmol} / \mathrm{l} \\
\text { (female } / \text { male, } \geq 30 \text { years): } 7 \% \text {; } \\
\quad>8.0 \mathrm{mmol} / \mathrm{l}: 2 \%\end{array}$ & \\
\hline $\begin{array}{l}\text { Mann et al, } \\
1988^{25}\end{array}$ & $\begin{array}{l}\text { BMI >25: } \\
46 \% \text { male, } \\
37 \% \text { female }\end{array}$ & $\begin{array}{c}\text { BP > 160/90: } \\
15 \% \text { male, } \\
10 \% \text { female }\end{array}$ & $\begin{array}{l}1 \% \text { male, } \\
1 \% \text { female }\end{array}$ & $\begin{array}{c}\text { TC > } 5.5 \mathrm{mmol} / \mathrm{l}: \\
58 \% \text { male, } 53 \% \text { female; } \\
\text { TC > } 6.5 \mathrm{mmol} / \mathrm{l}: \\
26 \% \text { male, } 24 \% \text { female; } \\
\text { TC > } 8.0 \mathrm{mmol} / \mathrm{l}: \\
4 \% \text { male, } 4 \% \text { female }\end{array}$ & \\
\hline $\begin{array}{l}\text { Bennett } \\
\text { et al, } 198917\end{array}$ & $\begin{array}{c}>10 \% \text { above } \\
\text { ideal BMI: } 42 \%\end{array}$ & $\begin{array}{c}\mathrm{DBP}>90 \text { on } \\
3 \text { readings: } 18 \%\end{array}$ & & $\mathrm{TC}>6.5 \mathrm{mmol} / \mathrm{l}: 27 \%$ & \\
\hline $\begin{array}{l}\text { Björkelund } \\
\text { et al, 199118 }\end{array}$ & $\mathrm{BMI} \geq 30: 13 \%$ & $\begin{array}{c}\text { BP }>160 / 95(<60 \text { years) } \\
\text { or }>170 / 105 \text { ( } \geq 60 \text { years) } \\
\text { or antihypertensive } \\
\text { medication: } 22 \%\end{array}$ & $\begin{array}{c}\text { FBG } \geq 5.5 \text { or } \\
\text { previously diagnosed } \\
\text { DM: } 2 \% \text {. Newly } \\
\text { detected DM: } 0.2 \%\end{array}$ & $\begin{array}{c}\mathrm{TC} \geq 9.0 \mathrm{mmol} / \mathrm{l} \\
\text { ( }<50 \text { years) or } \\
\geq 10 \mathrm{mmo} / / \mathrm{l} \\
(\geq 50 \text { years): } 3 \%\end{array}$ & \\
\hline $\begin{array}{l}\text { OXCHECK } \\
\text { Study } \\
\text { Group, } \\
1991^{14}\end{array}$ & $\begin{array}{c}\text { BMI 25-29: } 45 \% \text { male, } \\
\text { 32\% female } \\
\text { BMI } 230: 10 \% \text { male, } \\
16 \% \text { female }\end{array}$ & $\begin{array}{l}\text { DBP >90: } \\
14 \% \text { male, } \\
9 \% \text { female }\end{array}$ & & $\begin{array}{l}\text { TC } 6.5-7.9 \mathrm{mmol} / \mathrm{l} \text { : } \\
30 \% \text { male, } 29 \% \text { female; } \\
\text { TC } \geq 8.0 \mathrm{mmol} / \mathrm{l}: 8 \% \\
\text { for male and female }\end{array}$ & \\
\hline $\begin{array}{l}\text { Hellénius } \\
\text { et al, 199322 }\end{array}$ & $\begin{array}{c}\mathrm{BMI} \geq 30: \\
17 \% \text { male, } \\
14 \% \text { female }\end{array}$ & $\begin{array}{c}\mathrm{DBP} \geq 90: \\
33 \% \text { male, } \\
22 \% \text { female }\end{array}$ & $\begin{array}{l}\text { Blood glucose } \\
\geq 6.7: 12 \% \text { male; } \\
\quad 6 \% \text { female }\end{array}$ & $\begin{array}{c}\text { TC } \geq 5.2 \mathrm{mmol} / \mathrm{l}: \\
68 \% \text { male, } 62 \% \text { female; } \\
\text { TC } \geq 6.5 \mathrm{mmol} / \mathrm{l}: \\
29 \% \text { male, } 27 \% \text { female; } \\
\text { TG } \geq 2.3 \mathrm{mmol} / \mathrm{l}: \\
22 \% \text { male, } 10 \% \text { female }\end{array}$ & \\
\hline $\begin{array}{l}\text { Family Heart } \\
\text { Study Group, } \\
1994^{15}\end{array}$ & $\begin{array}{l}\text { Total population: } \\
\text { BMI } 25-29: 49 \% \text { male, } \\
31 \% \text { female BMI } \geq 30 \text { : } \\
\text { 13\% male, } 13 \% \text { female. } \\
\text { Apparently healthy } \\
\text { population: } \\
\text { BMI } 25-29: 49 \% \text { male, } \\
31 \% \text { female BMI } \geq 30 \text { : } \\
11 \% \text {, male, } 11 \% \text { female }\end{array}$ & $\begin{array}{l}\text { Total population: } \\
\text { DBP } \geq 90 \text { : } \\
38 \% \text { male, } 23 \% \text { female. } \\
\text { Apparently healthy } \\
\text { population: } \\
\text { DBP } \geq 90: 33 \% \text { male, } \\
18 \% \text { female }\end{array}$ & $\begin{array}{l}\text { Total population: } \\
\text { RBG } \geq 7: 12 \% \text { male, } \\
\text { 6\% female. } \\
\text { Apparently healthy } \\
\text { population: } \\
\text { RBG } \geq 7.0 \text { : } \\
10 \% \text { male, } \\
5 \% \text { female }\end{array}$ & $\begin{array}{c}\text { Total population: } \\
\text { TC } \geq 6.5 \mathrm{mmol} / \mathrm{l}: 22 \% \text { male, } \\
18 \% \text { female. } \\
\text { Apparently healthy } \\
\text { population: } \\
\mathrm{TC} \geq 6.5 \mathrm{mmo} / \mathrm{l}: \\
19 \% \text { male, } \\
16 \% \text { female }\end{array}$ & $\begin{array}{l}\text { A coronary risk score was } \\
\text { calculated; } 16 \% \text { of males } \\
\text { and } 15 \% \text { of females without } \\
\text { previously diagnosed } \\
\text { coronary heart disease } \\
\text { or self-reported chest pain } \\
\text { on exercise were in } \\
\text { the high-risk quintile }\end{array}$ \\
\hline $\begin{array}{l}\text { Persson } \\
\text { et al, } 1994^{32}\end{array}$ & & & & $\begin{array}{l}\text { TC } 6.5-7.8 \mathrm{mmol} / \mathrm{l}: 14 \% \\
\text { TC } \geq 7.9 \mathrm{mmol} / \mathrm{l}: 2 \%\end{array}$ & $\begin{array}{c}\text { A risk profile was worked out } \\
\text { with 'risk points' for different } \\
\text { risk factors }\end{array}$ \\
\hline
\end{tabular}


Table 4 continued. Overview of included screening initiatives, performed in a mixed population: yield of screening

\begin{tabular}{|c|c|c|c|c|c|}
\hline & \multicolumn{4}{|c|}{ Risk factors } & \multirow[b]{2}{*}{ Risk score } \\
\hline & Obesity & Hypertension & Diabetes & Dyslipidaemia & \\
\hline $\begin{array}{l}\text { Gran } \\
\text { et al, 199521 }\end{array}$ & & $\begin{array}{l}\text { DBP > } 90: 33 \% \text { male, } \\
22 \% \text { female }\end{array}$ & & $\begin{array}{c}\text { TC > 6.5 mmol/l: } \\
44 \% \text { in male, } \\
37 \% \text { in female }\end{array}$ & $\begin{array}{l}\text { A risk score was calculated but } \\
\text { the results cannot be extracted }\end{array}$ \\
\hline $\begin{array}{l}\text { Lauritzen } \\
\text { et al, } 1995^{24}\end{array}$ & $\begin{array}{c}\text { BMI }>30 \text { or } \\
\text { BMI 25-29 plus } \\
\text { WHR }>0.8: 16 \%\end{array}$ & $\begin{array}{l}\mathrm{SBP}>160 \text { or } \\
\mathrm{DBP}>90: 10 \%\end{array}$ & FBG $>7: 2 \%$ & $\mathrm{TC}>7 \mathrm{mmol} / \mathrm{l}: 10 \%$ & $\begin{array}{l}\text { Increased or very } \\
\text { high myocardial } \\
\text { infarction risk: } 11 \%\end{array}$ \\
\hline $\begin{array}{l}\text { Van den Berg } \\
\text { et al, } 1999^{26}\end{array}$ & $\mathrm{BMI} \geq 30: 11 \%$ & $\begin{array}{c}\text { SBP } \geq 160 \text { or } \mathrm{DBP} \geq 95: 30 \% \\
\text { Newly: detected } 5 \% \\
\text { hypertension and } \\
10 \% \text { isolated systolic } \\
\text { hypertension }\end{array}$ & $\begin{array}{c}7 \% \\
\text { Newly detected: } 2 \%\end{array}$ & $\begin{array}{l}\mathrm{TC} \geq 6.5 \mathrm{mmol} / \mathrm{l}: 26 \% \\
\text { newly detected: } 8 \%\end{array}$ & \\
\hline $\begin{array}{l}\text { Weinehall } \\
\text { et al, 199927 b }\end{array}$ & & $\begin{array}{l}\text { SBP } \geq 160: 30 \% \text { male, } \\
29 \% \text { female }\end{array}$ & & $\begin{array}{c}\mathrm{TC}>6.5 \mathrm{mmol} / \mathrm{l}: \\
46 \% \text { male, } 48 \% \text { female }\end{array}$ & \\
\hline $\begin{array}{l}\text { Bunescu } \\
\text { et al, 2008 }\end{array}$ & $\begin{array}{c}\text { BMI 25-30: } 35 \% \\
\text { BMI } \geq 30: 21 \%\end{array}$ & $\begin{array}{c}\text { BP >140/90 in patients } \\
\text { without comorbidity; } \\
>130 / 80 \text { in patients with DM, } \\
\text { congestive heart failure or } \\
\text { renal insufficiency; >125/75 } \\
\text { in patients with proteinuria } \\
>1 \mathrm{~g} / 24 \text { hours; or those } \\
\text { taking antihypertensive } \\
\text { medication: totally } 24 \%\end{array}$ & DM: $3 \%$ & $\begin{array}{l}\text { TC } \geq 190 \mathrm{mg} \%: 47 \% \\
\mathrm{TC} \geq 240 \mathrm{mg} \%: 12 \%\end{array}$ & $\begin{array}{l}\text { SCORE risk function }<5 \% \\
\text { without CVD or DM: } 60 \% \\
\text { SCORE risk function } \geq 5 \% \\
\text { without CHD or DM: } 30 \% \\
\text { SCORE risk function in patients } \\
\text { with CHD or DM: } 9 \%\end{array}$ \\
\hline $\begin{array}{l}\text { Tiessen } \\
\text { et al, } 2012^{28}\end{array}$ & & & & & $\begin{array}{c}\text { Low risk (SCORE <5\%): } 60 \% \text {; } \\
\text { aged }<65 \text { : } 78 \% \text {; aged } \\
\text { 50-55 (only males): } 92 \% \\
\text { Intermediate risk (SCORE 5-10\% } \\
\text { without additional risk factors): } \\
\text { 14\%. Increased risk (SCORE } \\
5-10 \% \text { with additional } \\
\text { risk factors or } \geq 10 \% \text { ): } 26 \%\end{array}$ \\
\hline
\end{tabular}

$B M I=$ body mass index in $\mathrm{kg} / \mathrm{m}^{2} . \mathrm{BP}=$ blood pressure in $\mathrm{mmHg} . C H D=$ coronary heart disease. $D B P=$ diastolic blood pressure in $\mathrm{mmHg}$. DM = diabetes $\mathrm{mellitus}$. $F B G=$ fasting blood glucose in $\mathrm{mmol} / \mathrm{l}$. IFG = impaired fasting glucose. $R B G=$ random blood glucose in $\mathrm{mmol} / \mathrm{l}$. SBP= systolic blood pressure in mmHg. TC = total cholesterol. $T G=$ triclycerides. WHR = waist to hip ratio; years: years. ${ }^{a}$ Only participants without $C H D$, peripheral arterial disease, and stroke were analysed. ${ }^{b}$ Results were extracted from another publication presenting the prevalence rates of cardiometabolic risk factors for the first 6 years of the Västerbotten Intervention Programme. ${ }^{33}$

this is the first systematic review, having systematically searched and assessed the literature, of screening programmes to identify individuals with an increased cardiometabolic risk in primary care. The screening studies were published between 1967 and 2012. Over the past 50 years the attitude towards screening for an increased cardiometabolic risk has changed. Earlier studies focus on the benefits of screening, whereas later publications search for the best way to screen. With increasing knowledge of benefits of treating cardiometabolic risk factors, the cut-off values for the separate risk factors have become stricter.

A time trend in eligible populations was also observed. Not until 1995 was the first study focusing on an apparently healthy population published. ${ }^{12}$ In the last 8 years, four of the five existing studies on apparently healthy populations were performed and only two studies in mixed populations were published. 19,20 This finding supports the authors' assumption that people with established CVD, diabetes, hypertension, or dyslipidaemia already receive further risk assessment and treatment through existing pathways; therefore screening among them should not be necessary.

Most published screening programmes were performed in England; no studies were found performed in the US. This might be because of the requirement for actively involving GPs, as the GP has a less strong gatekeeper function in the US. 
The first stepwise screening was published in 1993; ${ }^{22}$ the other three studies using a stepwise method were published in or after 2008.9.11,13 The latter studies all concerned apparently healthy populations. Particularly in these populations a stepwise method can be useful, as a substantial part of them will be healthy. A stepwise method will limit the number of people qualifying for elaborate examinations. A first step that requires action from the invited participants does not seem to influence the response rate compared with being invited for a total risk assessment at once. As only one study also invited a sample of people who did not qualify for further examinations after the first step, it was not possible to compare the discriminative ability of the different stepwise methods.

Sending reminders resulted in a higher screening uptake in apparently healthy populations. As expected, with an opportunistic approach the highest response rate was found with the longest study period.

Public awareness seems to be an important determinant of screening uptake. The highest response rate (93\%) was found by Weinehall et al who describe the results of the first 8 years of the Västerbotten Intervention Programme in Sweden. ${ }^{27}$ The individual screening strategy was combined with a population strategy by creating a local health promotion collaboration to raise public awareness. The opportunistic screening by Cope et al lasted 1 week, but the screening uptake was 39\%. ${ }^{4}$ The investigators advertised their health week in advance, within the general practice and by giving talks.

Devroey et al had an active approach but also the lowest response rate; people were invited by the local authorities to visit their GP for a health check. ${ }^{20}$ In most studies, people were invited by their GP; in no other study were the authorities responsible for inviting people. Six of the seven studies published in or after 2004 calculated a risk score; this reflects the increased use of risk scores in clinical practice. One might expect lower prevalence rates in an apparently healthy population than in a population with participants already diagnosed with risk factors. When comparing prevalence rates of hypertension, diabetes, or dyslipidaemia between healthy and mixed populations, no substantial differences were observed. From this, it can be concluded that a substantial part of the apparently healthy people have an increased cardiometabolic risk, which makes screening among this population worthwhile.

\section{Strengths and limitations}

Before discussing the yield of the screening programmes, some limitations of this systematic literature review need to be considered. As mentioned above, the cut-off values for risk factors have become stricter over the years, hindering the comparison of the yield over time. As a result of heterogeneity of used thresholds and risk scores, it was not possible to compare prevalence rates of cardiometabolic risk factors, nor relate the yield of the different studies to programme characteristics. Because most of the studies performed in mixed populations did not provide information about the composition of their study population, it was not possible to compare the yield of screening between healthy and mixed populations.

A systematic review often includes a risk of bias assessment of quality items like randomisation, selection bias, blinding, and loss-to-follow-up. The main interest in this study were cross-sectional aspects of screening; the focus was on the eligible population, screening method used, patient approach, response rate, and yield of screening. Because the focus was on 'how' rather than 'how well', no critical appraisal was performed on the above-mentioned items.

Another limitation of this study is that five articles were missed in the analyses as it was not possible to retrieve them full-text.

\section{Comparison with existing literature}

Ultimately, it is not the yield of the screening that makes sense, but the reduction of cardiovascular morbidity and mortality by early treatment of risk factors. Si et al examined the effect of screening versus no screening in general practice on surrogate endpoints, and found significant improvement in several cardiovascular risk factors, especially in high-risk populations. ${ }^{29} \mathrm{~A}$ Cochrane review, however, found no effect of health checks on total and cardiovascular mortality. ${ }^{30}$ The studies included in these reviews all started in the 20th century. As shown here, much has changed over the years, not only with regard to the characteristics of the screening programmes, but also with regard to new treatment insights.

Before implementing a screening programme it is first necessary to identify optimal programme efficiency, with regard to method and targeted population. This may influence the effects of screening on morbidity and mortality. In the authors' opinion, the optimal screening strategy should identify all people with an increased 
cardiometabolic risk, with a minimum effort to detect these people. Defining 'optimal' in such a way, the authors realise that not all the Wilson and Jungner criteria are taken into account, ${ }^{31}$ such as cost-effectiveness, or psychological harm. Screening might reduce the costs for treating diseases, but screening programmes are also expensive. Therefore, it is important to use the available resources as efficiently as possible. A stepwise approach is likely to be the best way to reduce these costs through selection of a high-risk population, reducing the number of further examinations. Future research will have to prove whether stepwise screening methods are indeed more cost-effective.

\section{Implications for research and practice}

As people with established disease or risk factors are likely to receive extensive care through existing chronic care pathways, screening programmes should focus on apparently healthy people.

Stepwise methods can limit the number of people qualifying for further examinations; a stepwise method, in which the first step requires action from the invited participants, does not seem to influence response rate.

An invitation, and if necessary reminders, sent by the GP, appears to increase screening uptake.

Increased public awareness of the opportunity and relevance of screening seem to lead to a higher screening uptake.

In this review, 26 screening programmes are described for detecting people with an increased cardiometabolic risk, performed in primary care. Observed time trends were the shift in focus from a mixed population to an apparently healthy population, an increased use of risk scores, and an increasing use of stepwise methods, especially in apparently healthy populations.

In apparently healthy populations a substantial number of people were detected with an increased cardiometabolic risk, stressing the need for ongoing detection. Stepwise methods, increasing public awareness, and actively involving GPs could improve screening efficiency and uptake. 


\section{REFERENCES}

1. World Health Organization. The Global Burden of Disease: 2004 Update. Geneva, Switzerland: WHO, 2008.

2. Gidman W, Ward P, McGregor L. Understanding public trust in services provided by community pharmacists relative to those provided by general practitioners: a qualitative study. BMJ Open 2012; 2: e000939

3. Chamnan P, Simmons RK, Khaw KT, et al. Estimating the population impact of screening strategies for identifying and treating people at high risk of cardiovascular disease: modelling study. BMJ 2010; 340: c1693

4. Cope JT, Smith DH. A health week in rural general practice. BMJ 1967; 2(5554): 756-758

5. Pike LA. A screening programme for the elderly in a general practice. Practitioner 1969; 203(218): 805-812.

6. Pike LA. Screening middle-aged men in a general practice. Practitioner 1972; 209(253): 690-695.

7. Scott R, Robertson PD. Multiple screening in general practice. BMJ 1968; 2(5606): 643-647.

8. Brown JS. A coronary screening programme in general practice. J R Coll Gen Pract 1978; 28(197): 735-742.

9. Godefrooij MB, van de Kerkhof RM, Wouda PJ, et al. Development, implementation and yield of a cardiometabolic health check. Fam Pract 2012; 29(2): 174-181.

10. Lambert AM, Burden AC, Chambers J, Marshall T. Cardiovascular screening for men at high risk in Heart of Birmingham Teaching Primary Care Trust: the 'Deadly Trio' programme. J Public Health (Oxf) 2012; 34(1): 73-82.

11. Marshall T, Westerby P, Chen J, et al. The Sandwell Project: a controlled evaluation of a programme of targeted screening for prevention of cardiovascular disease in primary care. BMC Public Health 2008; 8: 73.

12. McMenamin JP. Screening for coronary heart disease risk among men in a general practice. NZ Med J 1995; 108(999): 167-168.

13. van den Donk M, Bobbink IWG, Gorter KJ, et al. Identifying people with metabolic syndrome in primary care by screening with a mailed tape measure. A survey of 14,000 people in the Netherlands. Prev Med 2009; 48(4): 345-350

14. Prevalence of risk factors for heart disease in OXCHECK trial: implications for screening in primary care. Imperial Cancer Research Fund OXCHECK Study Group. BMJ 1991; 302(6784): 1057-1060.

15. British family heart study: its design and method, and prevalence of cardiovascular risk factors. Family Heart Study Group. Br J Gen Pract 1994; 44(379): $62-67$.

16. Anggard EE, Land JM, Lenihan CJ, et al. Prevention of cardiovascular disease in general practice: a proposed model. BrMed J (Clin Res Ed) 1986; 293(6540): 177-180

17. Bennett P, Blackall M, Clapham M, et al. South Birmingham Coronary Prevention Project: a district approach to the prevention of heart disease. Community Med 1989: 11(2): 90-96.
18. Björkelund C, Bengtsson C. Risk factor pattern for cardiovascular and cerebrovascular disease as observed in the female population of a Swedish community, Stromstad. Scand J Prim Health Care 1991; 9(1): 11-15.

19. Bunescu DM, Stoffers HE, van den Akker M, Dinant GJ. Coronary heart disease and cardiovascular risk factors among people aged 25-65 years, as seen in Romanian primary healthcare. Eur J Gen Pract 2008; 14(2): 56-64.

20. Devroey D, Kartounian J, Vandevoorde J, et al. Primary prevention of coronary heart disease in general practice: a cross sectional population study. Int J Clin Pract 2004; 58(2): 130-138.

21. Gran B. Major differences in cardiovascular risk indicators by educational status. Results from a population based screening program. Scand J Soc Med 1995; 23(1): 9-16

22. Hellénius ML, de Faire U, Krakau I, Berglund B. Prevention of cardiovascular disease within the primary health care system - feasibility of a prevention programme within the Sollentuna primary health care catchment area. Scand J Prim Health Care 1993; 11(1): 68-73.

23. Jones A, Davies DH, Dove JR, et al. Identification and treatment of risk factors for coronary heart disease in general practice: a possible screening model. Br Med J (Clin Res Ed) 1988; 296(6638): 1711-1714.

24. Lauritzen T, Leboeuf-Yde C, Lunde IM, Nielsen KD. Ebeltoft project: baseline data from a five-year randomized, controlled, prospective health promotion study in a Danish population. Br J Gen Pract 1995; 45(399): 542-547.

25. Mann Jl, Lewis B. Shepherd J, et al. Blood lipid concentrations and other cardiovascular risk factors: distribution, prevalence, and detection in Britain. BMJ (Clin Res Ed) 1988; 296(6638): 1702-1706.

26. van den Berg PJ, van Dalsen CL, de Rooij RA, et al. Cardiovascular health check in the elderly in one general practice: does it offer new information and lead to interventions? Fam Pract 1999; 16(4): 389-394.

27. Weinehall L, Westman G, Hellsten G, et al. Shifting the distribution of risk: results of a community intervention in a Swedish programme for the prevention of cardiovascular disease. J Epidemiol Community Health 1999 53(4): 243-250

28. Tiessen AH, Smit AJ, Zevenhuizen S, et al. Cardiovascular screening in general practice in a low SES area. BMC Fam Pract 2012; 13: 117.

29. Si S, Moss JR, Sullivan TR, et al. Effectiveness of general practice-based health checks: a systematic review and meta-analysis. Br J Gen Pract 2014; DOI: 10.3399/bjgp14X676456

30. Krogsboll LT, Jorgensen KJ, Gronhoj LC, Gotzsche PC. General health checks in adults for reducing morbidity and mortality from disease: Cochrane systematic review and meta-analysis. BMJ 2012; 345: e7191.

31. Wilson JMG, Jungner G. Principles and practice of screening for disease. Public Health Papers nr 34. Geneva: WHO, 1968

32. Persson LG, Lindstrom $K$, Lingfors $H$, Bengtsson $C$. A study of men aged 33-42 in Habo, Sweden with special reference to cardiovascular risk factors. Design, health profile and characteristics of participants and nonparticipants. Scand J Soc Med 1994; 22(4): 264-272.

33. Brannstrom I, Persson LA, Wall S. Gender and social patterning of health: the Norsjo cardiovascular preventive programme in northern Sweden 1985-1990. Scand J Prim Health Care 1994; 12(3): 155-161. 